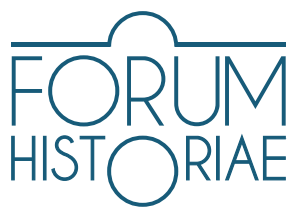

\title{
"Here a prosecutor fraternizes with a smuggler." Complicated Links Between the Mountains, Economics and Ideology
}

\author{
Jerzy Kochanowski
}

\begin{abstract}
KOCHANOWSKI, Jerzy. "Here a prosecutor fraternizes with a smuggler." Complicated Links Between the Mountains, Economics and Ideology.

The conclusion of the state commissioned report addressed to Zakopane in 1972 was: "in Zakopane, the state is in a position worse than in capitalism. It has been reduced to the role of not even a night-watchman, but that of an unpaid street-sweeper". This peculiar "autonomy" of the Podhale Region was affected by historical, social, cultural and geographical conditions that are commonly mentioned, though on the other hand, the state was also an important actor and nowise ambiguous. The tendency to take up strict supervision of sectors decisive for the image and importance of Zakopane and the Tatra region-tourism and sport-existed at the central level from the mid-1950s to the 1980s, but at the regional level, these policies encountered strong resistance. The reason was an emergence of specific social networks linking the private sector with the structures of local government, state and party, or even with the police and judicial departments, however, only thanks to them was it possible - due to the organizational inefficiency of the state-to fulfil a societal need for the modernization of leisure and related services, which grew suddenly after 1956. Only in the first half of the 1970s was the socialist state able to provide a relatively rational program thanks to being an influential factor in modernization, mostly due to maintaining control of material resources. However, in the period of disintegration of the system, the end of the 1970s and in the 1980s, the state's program was no longer a barrier or alternative for the social actors.
\end{abstract}

Keywords: Zakopane, Podhale region, tourism, private sector, social networks, 1956-1970, Polish United Worker's Party

DOI: https://doi.org/10.31577/forhist.2021.15.2.4

CC That the Waluś family were persecuted in Poland, that they had to flee the country and that Kuba saved the world from communism was something we learned a few years later. I have to admit I was stunned when I read those incredible lies. They were very well-off and concentrated on their own business and money. They kowtowed to the commies, were making the most of life and there was no ideology there." That "Kuba", an idol of today's extreme right in Poland, is Janusz Jakub Waluś. In 1981, he emigrated to South Africa, where he later killed leader of the South African Communist Party Chris Hani in 1993. In the construction of Waluś' legend ${ }^{2}$ by the extremists, an important factor

This article has been written as part of the Polish National Science Centre-founded project no. 2014/15/G/ HS3/04344 "Room for Manoeuvre in State Socialism: Between Adaptation and Experiment".

1 ŁAZAREWICZ, Cezary. Janusz Waluś, historia rodzinna mordercy antykomunisty. "Mimo bogactwa zawsze mieli otwarte serce". In Gazeta Wyborcza, 11 May 2020, https://wyborcza.pl/alehistoria/7,121681,25697735,janusz-walus-bananowy-mlodzieniec-ktory-zostal-morderca-na.html [last viewed: 7 October 2021]. For more see ŁAZAREWICZ, Cezary. Nic osobistego. Sprawa Janusza Walusia, Katowice: Wydawnictwo Sonia Draga, 2019.

2 ŁAZAREWICZ 2019; GRELA, Szymon. Rasista Waluś w Polsce. Jak polska prawica polubiła mordercę. In OKO. Press, 21 April 2017, https://oko.press/rasista-walus-polsce-polska-prawica-polubila-morderce/ [last viewed 7 October 2021]; KORZYCKI, Radosław. Janusz Waluś, Heros kiboli i prawicy. In Gazeta Wyborcza, 26 May 2017, https://wyborcza.pl/magazyn/7,124059,21870313,janusz-walus-heros-kiboli-i-prawicy.html [last viewed: on 7 October 2021]. 
legitimising his anti-communist stance was the mere fact that he was born in Zakopane, in the Tatra Mountains (1953). His parents, however, were not highlanders but the so-called "cepry", or lowlanders from other regions of the country and the guest house they ran was not so much a source of income but a convenient platform for interaction with government authorities. Its guests included VIPs from both Kraków and Warsaw, which undoubtedly made it easier, especially in the Stalinist period, for the family businesses to survive, both the inn and private factories run by Walušs father. It was also no coincidence that Janusz Walus' godmother was the daughter of Kiejstut Żemaitis, a communist dignitary, who in 1949-1959 was in charge of Poland's heavy industry. ${ }^{3}$

The above, by no means unique, example shows how far removed from reality the stereotypical, simplified picture of relations was between the government and society in the years 1945-1989, a distinct image rooted in the collective memory and reproduced in journalism and historical narratives. Even in the case of the highlanders from the Podhale region, who are commonly believed to have been in organisational and political conflict with the communist state, ${ }^{4}$ the true scope of their relationship was much broader, varied and sometimes surprising in its forms. The authors of a 1972 party report even noted that "in Zakopane, the state is in a position worse than under capitalism. It has been reduced to the role of not even a night-watchman, but of an unpaid street sweeper." ${ }^{5}$ In all socialist countries, quite sizeable space existed in which the state, more or less (un)intentionally and (un) consciously, left the citizens some room for manoeuvre, while a host of social actors-private and institutional-blended the communist system's behavioural logic with their own interests, goals and values, choosing among the norms imposed on them from above those which they could adopt for their own benefit, without much personal harm. ${ }^{6}$ This required both sides to cross the boundaries of ideology, norms or law, to be ready for far-reaching compromises and be willing to engage in unique, informal negotiations marking-often unconsciously and spontaneously - the boundaries of mutual concessions, and ultimately to tacitly relinquish mutual prejudices and establish some-unverbalised-trust. The following remarks on Zakopane and its surroundings focus on the most characteristic and interlinked spheres of ideology and economics. It is no coincidence that the title lacks a detailed timeframe; while the article focuses on the period of 1956-1970, it also tackles earlier and later threads. ${ }^{7}$

The uniqueness of the Podhale region and Zakopane, stressed even in party documents, was and continues to be, a consequence of the peculiarities of communities living in high

3 ŁAZAREWICZ 2020.

4 KORKUĆ, Maciej. Podziemie niepodległościowe pod Tatrami 1945-1949. In ZACHARKO, Jerzy (ed.) Drogi do Niepodległości. Polska, Podhale, Zakopane 1945-1989. Zakopane : Gmina Miasto Zakopane, 2005, pp. 13-46; Niepodległość pod wierchami. Z Maciejem Korkuciem i Wojciechem Szatkowskim rozmawia Dawid Golik. In Biuletyn IPN, No. 1-2, 2010, pp. 3-18.

5 KOCHANOWSKI, Jerzy. Socjalizm na halach, czyli "Patologia stosunków społeczno-ekonomicznych i politycznych w Zakopanem” (1972). In Przeglad Historyczny, 2007, Vol. 98, No. 1, p. 86.

6 See Przeglad Historyczny, 2018, Vol. 109, No. 4, devoted entirely to the "room for manoeuvre" in the Polish People’s Republic, Czechoslovakia, Romania and German Democratic Republic, http://www.przegladhistoryczny.pl/ content/przegl\%C4\%85d-historyczny-t-cix-2018-z-4 [last viewed: 1 July 2020].

7 I tackle the problem of relations between the government and society in the Podhale region in e.g. KOCHANOWSKI, Jerzy. "Wolne miasto?". Nieco inne spojrzenie na Zakopane Władysława Gomułki, 1956-1970. In Przeglad Historyczny, 2018, Vol. 109, No. 4, pp. 611-649; KOCHANOWSKI, Jerzy. "Złudzenie, ale jakże przyjemne" czyli stalinizm w Zakopanem. In HRYCIUK, Grzegorz - RUCHNIEWICZ, Małgorzata - SREBRAKOWSKI, Aleksander (eds.) Spojrzenia nie tylko na wschód. Od Dolnego Śląska po Syberię. XX wiek w historii, historiografii i naukach politycznych. Toruń : Adam Marszałek, 2019, pp. 341-353; KOCHANOWSKI, Jerzy. "Wolne miasto?". Zakopane 1956-1970. Kraków : ZNAK, 2019. 
mountains all over the world, communities often radically different in historical, economic, ethnic or ethnographic, political or cultural terms from their lowland compatriots. ${ }^{8}$ In the characteristically peripheral mountain regions, the state and its institutions were something remote, less important than one's own surroundings, local community and extended family. This limited the control on the part of the political centre led to the highlanders' weaker identification with state symbols, and at the same time amplified the role of local dialects, customs or dress as identifying features. From the perspective of the usually lowland centre, mountain communities were seen as backwards and conservative. This was usually true, though at the same time a typical frontier nature coupled with prominent identification factors and the highlanders' disregard for political borders led to the emergence of unique cultural melting pots. For a long time treated as an obstacle, from the $19^{\text {th }}$ century onwards, the mountains became an attraction, even a mass attraction from the second half of the $20^{\text {th }}$ century, while leisure, tourism and sport began to attract more than just elites, a change that revolutionised local social and economic relations and radically drove the government's interest in the mountains and in people residing there.

The Podhale region, especially its high mountain, "rocky" part including Zakopane, fits this model perfectly: it was a poor region, the local community stood out by virtue of its dialect, different customs and mentality including a unique value scale, a significant role of the family unit and neighbourhood as well as an original spiritual and material culture. As agriculture alone did not guarantee survival, other strategies were commonly employed such as migration, smuggling and from the late $19^{\text {th }}$ century, tourism services. During the inter-war period, Zakopane became the most important resort destination in Poland, while remaining a strong cultural centre to visit, which was a must for the elites and also a large part of the middle class. In 1938, the resort town attracted nearly 60,000 visitors, four times as many as before the First World War. ${ }^{9}$ It was also the country's most important winter sports centre, hosting the FIS championships twice (1929 and 1939). ${ }^{10}$ No wonder that in the Second Republic of Poland (1918-1939), large infrastructure investment projects (cableways to Kasprowy Wierch and Gubałówka, ski jumping hills, transport modernisation, etc.) were financed mainly by the state, which also did not interfere with construction, the domain of private investors, both local and non-local. As a result, the town, which grew twice as big in 1922-1939 (1620 buildings were constructed) was chaotic, unplanned and full of conflicting landscape and architecture. ${ }^{11}$ Changes were also visible in politics. At the beginning of the Second Republic of Poland, the conservative and outspokenly religious

8 See DEBARBIEUX, Bernard - RUDAZ, Gilles. The Mountain. A Political History from the Enlightenment to the Present. Chicago; London : University of Chicago Press, 2015; JENTSCH, Christoph. Für eine vergleichende Kulturgeographie der Hochgebirge. In Mannheimer Geographische Arbeiten, 1977, No. 1, pp. 57-71 (Beiträge zur geographischen Methode und Landeskunde. Festgabe für Gudrun Höhl); FUNNEL, Don - PARISH, Romola. Mountain Environments and Communities. London; New York : Routledge, 2001; BILLINGS, Dwight B. - KINGSOLVER, Ann E. (eds.) Appalachia in Regional Context: Place Matters. Lexington : Kentucky University Press, 2018.

9 See DUTKOWA, Renata. Zakopane. Czterysta lat dziejów 1, 2. Kraków : Krajowa Agencja Wydawnicza, 1991.

10 SZATKOWSKI, Wojciech. Z dziejów narciarstwa w Tatrach polskich (1894-2004). In ROSZKOWSKI, Jerzy N. - KOWALSKI, Robert (eds.) Góry i góralszczyzna w dziejach i kulturze pogranicza polsko-słowackiego (Podhale, Spisz, Orawa, Gorce, Pieniny). Historia. Nowy Targ : Podhalańska Wyższa Szkoła Zawodowa, 2005, pp. 135-142; BARANIAK, Maciej. Mistrzostwa Świata Międzynarodowej Federacji w Zakopanem w 1929 r. i 1939 r. In Prace Naukowe Akademii im. Jana Długosza w Częstochowie Seria: Kultura Fizyczna, 2010, No. 9, pp. 87-100.

11 Archiwum Akt Nowych (Archives of Modern Records - AAN), Collection Instytut Turystyki (Institute of tourism - IT), signature (sign.) 1069, Anna Kołodziejczyk, Wpływ turystyki na ewolucje socjo-kulturowa regionu Zakopanego od roku 1900 do czasów najnowszych (1977), 1978, p. 13; LOHMANN, Jerzy. Zakopane znaczy marzenia. In Kierunki, 4 December 1960; KOCHANOWSKI, Jerzy. A 'Free City'? The Zakopane of Władysław Gomułka, 1956-1970. In KOCHANOWSKI, Jerzy - KRAFT, Claudia (eds.) Rooms for Manoeuvre. Another Look at Negotiating Processes in the Socialist Bloc. Wien/Göttingen : V\&R Unipress, 2021, p. 121. 
residents of the Podhale region voted mainly for the Christian democratic right in the 1930s - primarily Piłsudski's ruling party. ${ }^{12}$

A consensus emerged regarding the relations between the authorities and society during and shortly after the Second World War. In war time, some residents of the Podhale region accepted the Nazi occupiers' offer to create a "highlander nation" (Goralenfolk), considering it a survival strategy, not collaboration. ${ }^{13}$ At the same time, Podhale became an important centre of armed resistance, which continued even after the war against the county's communist authorities.

The communists - characteristically - were quite understanding when it came to the particulars of the Podhale region. As was noted in 1961, "the communist authorities-like the Nazis before them-have granted, perhaps tacitly, a privileged status to the highlanders. This probably stems from the difficulties that would arise if socialism were to be introduced in the region. [...] But the reasons do not really matter to the highlanders, the main thing was that there are no kolkhozes, they are not forced to join the party and the taxman imposes relatively low taxes-given their earnings-on them." ${ }^{14}$ The reason was twofold: the problem of introducing communist principles into "autonomous" highlander communities - also seen in other countries of the Soviet bloc including the USSR, and purely practical considerations. This includes the fact that without the local community, the authorities would not have been able to satisfy citizens' growing consumer needs, including a-not necessarily formal share-in the profits generated. Also important was the legitimacy and prestige of the Podhale region, especially Zakopane, which became as important to the communist elites as it had been for their pre-war predecessors from the sanacja regime. ${ }^{15}$ They spent their holidays there in luxury conditions and welcomed official foreign guests. Symbolic concessions to the local population were not surprising either, including consent given to the existence of highlanders' associations after 1956, or reinstatement of the traditional uniform of military mountain units.

On the other hand, though people from the Podhale region were not particularly fond of the post-war government, especially its financial branch, until the late 1970s and early 1980s, they were quite far from getting involved in political forms of resistance on a mass scale. Reports by the Security Service did not record any special issues during parliament or national council elections. During the crises of 1968 and 1970, the highlanders were quite stoic, unlike the intelligentsia of non-local origin, and their only concern in De-

12 Muzeum Tatrzańskie Zakopane (Tatra Museum Zakopane - MTZ), AR/188, Elections to the Sejm and Senate in November 1922, pp. 29-30; PANZ, Karolina. Powiat nowotarski. In ENGELKING, Barbara - GRABOWSKI, Jan (eds.) Dalej jest noc. Losy Żydów w wybranych powiatach okupowanej Polski. 2. Warsaw : Stowarzyszenie Centrum Badań nad Zagładą Żydów, 2018, p. 222; BUSZKO, Józef - PILCH Andrzej. Narodziny miasta. Zakopane w latach 1918-1939. In DUTKOWA, Renata (ed.) Zakopane. Czterysta lat dziejów. 1. Kraków : Krajowa Agencja Wydawnicza, 1991, pp. 247-248, 264-265, 276-277.

13 SZATKOWSKI, Wojciech. Goralenvolk. Historia zdrady. Zakopane : Firma Ksiegarsko-Wydawnicza Kanon, 2012; TREBUNIA-STASZEL, Stanisława. "Lud zdolny do życia". Górale podhalańscy w oczach niemieckiego okupanta. Warsaw : Liber Pro Arte, 2019; SZURMIAK, Katarzyna. Goralenvolk: An "Aryan" Minority in Southern Poland and Its Treatment by the Nazis. In WEISS-WENDT, Anton (ed.) Eradicating differences, The Treatment of minorities in Nazi-dominated Europe. Newcastle upon Tyne : Cambridge Scholars Publ., 2010, pp. 85-102; KOCHANOWSKI 2021, p. 121.

14 Herder-Institut Marburg (HIM), P-6221, 2823/61, "Gorale" (the highlanders) - the privileged class in Poland, 3 September 1961.

15 Sanacja (sanitation) is a term applied to the political movement led by Józef Piłsudski and the regime that was set up after the armed coup in May 1926. The term derives from the regime's declared intention to carry out a moral "sanitation" of the Polish nation. 
cember 1970 was whether the new government would hinder their economic migration to North America. ${ }^{16}$

Unfortunately, research into the political attitudes of people living in the Podhale region began only in the 1990s, but presumably it largely reflected earlier views as well. An analysis of the highlanders' attitude towards the notion of freedom carried out at the time revealed that they linked the term primarily with economic freedom and not political freedoms, something of no special interest to them. ${ }^{17}$ It seems that various economic relations-partly parasitic, partly symbiotic-determined the form of contact between the local community and the state with institutions in Zakopane and the Podhale region. There is no doubt that in Zakopane, room for negotiation was available on both sides, society and the state, a condition substantially different from that of the rest of the country. Each party was constantly testing how far concessions could go, eventually recognising-at least for some time-that they had a common goal and that a consensus paid off.

\section{Feedback - The Mountains and the Party}

The diverse social picture of Zakopane was first highlighted in the late $19^{\text {th }}$ century. This continued in the Polish People's Republic. "At the tables sit people of from all walks of life," is how a well-known Zakopane establishment was described in 1960, "freebooters, swindlers, smugglers and traders, and among them, surprisingly, local communist dignitaries! Here a prosecutor fraternizes over a glass of vodka with a smuggler, a policeman with a foreign currency dealer, a petty swindler with a town councillor, a party secretary with a trader selling shoes smuggled from Czechoslovakia. They have fun and do business." 18 Twenty years later, the town was still seen as a place where a "black-market money changer has a government minister for a neighbour, a smuggler - a highland farmer from a family going back several centuries, a backpacker-a bishop." 19 This "ecumenism" was the fruit of the unique history of Zakopane, which from the very beginning had attracted-like a port town-people from various regions, social groups and walks of life. After the Second World War, the material and cultural attractiveness of the town helped to "domesticate" the local party as well as government structures, national and local.

After the war, the government brought oppression to the Podhale region but also a radical improvement in the standard of living for ordinary people. There was a significant improvement of the infrastructure (electrification, water supply, roads) and better access to education, healthcare, social welfare. In particular, it became easier to get a permanent job, in factories or holiday centres for example, with a fixed salary and working hours. This was becoming important for more and more of the population; in 1950, 76.5\% of workers were employed in agriculture, twenty years later that number fell to just 53.8\%. A dramatic increase in employment came in industry and crafts, construction, transport and communication, services, education and healthcare. ${ }^{20}$ State-owned enterprises were another area

16 Instytut Pamięci Narodowej Kraków Kraków (IPN Kr), 030/32, Jan Roszkowicz, Informacja o sytuacji politycznej powstałej na terenie Zakopanego po VII Plenum KC PZPR, 7 January 1971, p. 285.

17 KRZEŚNIAK, Agnieszka. Góralskie pojmowanie wolności. In MALEWSKA-SZAŁYGIN, Anna. Rozmowy z góralami o polityce. Warsaw : TRIO, 2005, p. 143.

18 HIM, P-051, 1662/60, Shady characters and free spending party men set pattern of Zakopane night life, 3 May 1960.

19 CIEMIŃSKI, Ryszard. Portret w kolorze żółtym. In Prawo i Zycie, 24 May 1981.

20 AAN, IT, sign. 1069, Anna Kołodziejczyk, Wpływ turystyki na ewolucje socjo-kulturowa ludności góralskiej regionu Zakopanego od roku 1900 do czasów najnowszych (1977), pp. 60-61, 121; CZARKOWSKA, Wanda - LESZCZYCKA, Wanda. Przemiany gospodarcze w regionie Podhala. In Wierchy, 1961, Vol. 30, pp. 30-46; 
where the highlanders were connected to the "government" and politics, especially the Polish United Workers' Party, which was-also for non-members-the highest authority people went to with problems in their private lives or work. Paradoxically, this role of a "court of appeal" and mediator played by the basic party cells was "the biggest asset of a state-owned enterprise."21

We still know very little about the effect of the communist party on peripheries and can only presume that economics triumphed over ideology and informal relations over "democratic centralism" more easily and more often than in big cities. On the other hand, there is no doubt that the authorities in Zakopane achieved a level of perfection in both. This was largely thanks to the characteristics of the Zakopane party structure and the conditions in which they operated. Traditionally, there was no left-wing base in the Podhale region and as a result, the Party organisation in Zakopane was not so much a party of workers and farmers, but of intellectuals and directors. Their percentage of workers was consistently much lower than recommended, never exceeding $25 \%$, while that of the intelligentsia was always much higher, sometimes over $70 \%$. Party membership in general was low, around $6-7 \%$ of adult residents of Zakopane, and many basic party cells were in fact Potemkin villages, existing only on paper.

A substantial part of the cadre was created out of necessity from functionaries sent to Zakopane from elsewhere, people who were inexperienced and chosen randomly and above all, did not understand the specifics of the region and the complexity of the local circumstances. Often, they also sought financial success over political careers, a feat not difficult to achieve in Zakopane. This led to constant turnover, though those who left their positions within party structures would often remain in Zakopane, maintaining roles but in more profitable positions, for instance as managers of holiday resorts, shops or restaurants, which were important elements of the informal local networks. "Many of them have managed to settle in Zakopane," a Kraków daily wrote about party immigrants in 1961, "hence their tendency to become friends with the highlanders, to turn a blind eye to their vices. Instead of becoming educators [...] the newcomers remain passive at best." ${ }^{\prime 2}$ They usually remained passive, but not for free. The particulars of Zakopane, a town of "horrible townsfolk converting people into money", ${ }^{23}$ provided a chance-in exchange for skilful "understanding" - for material advancement likely not achievable elsewhere in Poland on such a scale. A report compiled in mid-1972 by a party commission from Warsaw pointed to the phenomenon "of people coming to Zakopane from elsewhere to take up various posts becoming quickly rich: 'a man comes with a small suitcase,' they said, 'two years later he has a car, three more years and he has a villa"' ${ }^{24}$ On the other hand, it is not surprising that the party increasingly came to be seen as a convenient tool for accelerating one's financial career. ${ }^{25}$

CZARKOWSKA, Wanda - LESZCZYCKA, Wanda. Region Podhala w 25-lecie PRL. In Wierchy, 1971, Vol. 39, pp. 163-176.

21 MALEWSKA-SZAŁYGIN, Anna. Podhale - raj natury czy kombinat. In Opcja na prawo, http://www.opcjanaprawo.pl/index.php/grupa-rzeszowska-sp-1218852595/komunikat-sp-2032361976/item/3436-podhale-rajnatury-czy-kombinat [last viewed: 8 October 2021].

22 DUDZIK, Zdzisław. Zakopiański pępek. In Dziennik Polski (Kraków), 22-23 October 1961.

23 ADAMIECKI, Wojciech. Taniec $z$ nożami. Warsaw : Państwowe Wydawnictwo "ISKRY", 1975, pp. 207-208.

24 KOCHANOWSKI 2007, p. 80.

25 KOCHANOWSKI 2007, p. 94. 
Indeed, maintaining a hard ideological line in Zakopane was not easy. As early as 1957, there emerged a belief that "the tendency in the party is to succumb to petty bourgeois and the liberal moods of non-party circles rather than the party influencing these circles." ${ }^{26}$ In the following decade, a wave of guests brought not only money to Zakopane, but also new models which many party members could not resist. "Those who come here on holiday," came an observation in 1966, "are mainly dignitaries and their families from various Polish towns and cities, a significant percentage of them from Warsaw. [...] While they do not go to church back home where they may be regarded as atheists, here on holiday they do, often even by car. The local party members watch this passively as do the local residents. This [...] has a demoralising effect." 27

The above statement inadvertently points to an important factor influencing the behaviour of the Zakopane establishment, namely close links to Warsaw. Thanks to a visit by members of the top leadership, Zakopane came to be regarded as a "town to which ordinary regulations do not apply, and neither do ordinary procedures or ordinary chain of command. [...] The local authorities in Zakopane often come to the conclusion that our state dignitaries work in Warsaw basically only to deal with Zakopane's problems." 28 This was a highly symbiotic set-up: Zakopane residents, referred to as "invalids" because "they have their backs in Warsaw", ${ }^{29}$ took great care of their guests from the capital, who in turn guaranteed help in difficult matters or conflicts, or a safety net when the locals stumbled. And such opportunities were highly likely, given the frequent turning of a blind eye.

\section{"You don't bother me, I won't bother you" - Eyes Wide Shut}

In the last few years of Gomułka's rule, the party structures in Zakopane became fossilised and the "human resources policy" consisted largely of appointing people to managerial positions depending on their proximity to those in power, and placing trusted men in key, profitable positions. According to a 1972 assessment, "the executive of the Municipal Committee [...] was [...] more of an observer than an actor. Power was exercised through direct contacts between the first secretary of the Municipal Committee, and directors of enterprises, managers of various institutions. Hence their special role in the life of Z[akopane]. Some party members view this directorial group, holding tightly on to their posts, as the real governing body in Z[akopane]." ${ }^{30}$ The wide clientelist networks caught not only party functionaries, but also policemen, sports activists and people employed in the justice system, inland revenue and customs, etc. Some informal groups were established for a limited period for the purpose of a specific venture, others lasted longer. There were also those based on immediate and extended family, which-given the unique "family code" in the Podhale region-guaranteed both effectiveness and security.

26 AN Kr, Komitet Miejski Polskiej Zjednoczonej Partii Robotniczej (KM PZPR) Zakopane, 29/2272/34, Działalność zakopiańskiej organizacji partyjnej za okres od 1 grudnia [1956] do 26 marca p19[57], 26 March 1957.

27 AN Kr, Komitet Wojewódzki (KW) PZPR, 277, Posiedzenie Egzekutywy KW PZPR w Krakowie, 7 October 1966, p. 111.

28 DUDZIK 1961, Zakopiański. The same journalist had written one week earlier: "the local authorities think very highly of themselves. For them, the supervising institution in Kraków is no great authority, for in Zakopane they too often meet ministers, deputy prime ministers [...] Delusions about one's own contacts with the highest authorities in the country seriously undermine the official equilibrium. Instead of diligently doing their job, some 'statesmen' from Zakopane help with big politics. I'm really afraid that big politics will not benefit at all from this, but Zakopane will suffer greatly...” DUDZIK, Zdzisław. Po prostu Zakopane. In Dziennik Polski (Kraków), 15-16 October 1961.

29 Z kogo i dla kogo żyje Zakopane. In Dziennik Polski (London), 22 July 1959.

30 KOCHANOWSKI 2007, p. 94. 
For a characteristic example, imagine a policeman born and working in Zakopane. His highlander roots obligate him to treat the locals appropriately. "He is very approachable and very popular. [...] You can complete all the formalities connected with a trip to Czechoslovakia 'privately' with him, but he does it for free, wanting to win the sympathy of the town residents. He is probably a party member, but one guided by common sense and above all, he is Pole." ${ }^{31}$ On the other hand, he tries to satisfy his policing duties as loyally as possible but complains that "the fight against economic crime is very hard and difficult. There are cases when a thief is found, but there is no victim. No institution is willing to admit it has suffered losses." 32

There is no doubt that the networks developed in Zakopane also entangled judges or prosecutors, which is suggested by the extremely low percentage of cases going to court. ${ }^{33}$ Yet the most evidence in the sources has been left by police officers, or the People's Militia. They made up a considerable group of over 100 individuals in the early 1970s, one with the closest links to the local community. Lower salaries prompted them to turn a blind eye to, for example, illegal construction, production or trade. There were also cases of policemen collaborating with criminal gangs involved in smuggling as well as trading in foreign currencies and gold. As income from the tourism boom in the second half of the 1960s grew, investigation of serious crime decreased with the local police focusing on only minor cases. ${ }^{34}$ In addition, officers coming to Zakopane from outside quickly established relationships with highlander families, which was not without influence on their work. For example, a sergeant married into a family which owned a private workshop with an annual turnover of one million zlotys, an astronomical amount in the 1960s. ${ }^{35}$ There is plenty of information about relationships between policemen and barmaids, buffet attendants and waitresses working in second-rate establishments "because of decent salaries and the possibility of getting a drink..."36

\section{"Zakopane Consortium" - Jumping Over Barriers Together}

Nevertheless, these were matters of minor importance to the (in)formal coexistence of the authorities and society in Zakopane and the Podhale region. The main arena of collaboration was tourism, which was developing rapidly from the late 1950s. While Zakopane welcomed 960,000 visitors (including 23,000 foreigners) in 1959, a decade later that number rose to nearly 2,800,000 (including 245,000 foreigners). ${ }^{37}$ In addition, visitors wanted to spend their time in Zakopane in better, more intimate conditions. However, the last large investment in tourist accommodation had been the Dom Turysty (Tourist House), opened in 1958, in which most beds were in dormitories. The following decade saw no new hotel for "non-organised", moderately well-off tourists constructed. The situation was alleviated, to some extent, by holiday houses owned by enterprises, artists' associations etc., but

31 HIM, P-051, 1391/59, Peoples Militia in Zakopane, 18 April 1959.

32 AN Kr, KM PZPR Zakopane, 29/2272/74, Posiedzenie Egzekutywy KM PZPR w Zakopanem, 24 June 1959.

33 AN Kr, KM PZPR Zakopane, 29/2272/95, Informacja o stanie realizacji uchwały Egzekutywy KW PZPR w lipcu 1965 r. w sprawie dalszego wzmożenia ochrony mienia społecznego w Zakopanem w roku 1969.

34 AN Kr, KM PZPR Zakopane, 29/2272/99, Protokół posiedzenia Egzekutywy KM PZPR w Zakopanem, 25 February 35 Ibid. 1972, "Ocena stanu moralno-politycznego aparatu MO i SB w KM MO w Zakopanem".

36 Ibid.

37 AAN, IT, 1069, pp. 27, 35-37. 
in the mid-1960s, they were forbidden to build their own guest houses. The only solution lay in private construction but potential investors, both local and especially those coming from outside the city, came up against increasingly high barriers: protracted official procedures, lack of development plans, limitations associated with nature conservation etc. Overcoming these obstacles required the establishment of an informal consortium within which several social and institutional actors operated in a non-formalised symbiosis: 1) local residents with assets (land, money, social capital) needed for investment projects, 2) enterprises (sometimes from the central level) buying or renting guest houses built by the first group, 3) state or cooperative travel agencies acting as intermediaries between groups 1 and 2,4) municipal authorities relieved of the duty to take care of "open" tourist accommodations and to argue with e.g. enterprises over the construction of their own houses by private contractors, 5) groups mentioned in the previous subchapter-from the government in Warsaw to local policemen gaining various material and non-material benefits from Zakopane's social networks.

Obviously, this symbiotic set-up was centred around the local highlander families, which had at their disposal the most important assets-they owned half of the land in Zakopane as well as social and material capital. They also had close and pragmatic relations with the local authorities, whose ineptitude and negligence was a source of substantial profits. Characteristically, immediately after 1956 when Wiktor Pękała, president of the Presidium of the Municipal National Council who was elected following the wave of the "October" revolution, was making plans to "Europeanise" Zakopane and invest in its accommodation infrastructure, many locals supported Kazimierz Moździerz, the local party secretary who preferred workers' holidays. The reason was not the locals' respect for the Polish United Workers' Party, but a hope that an egalitarian vision of Zakopane would provide them with income for years to come, and also, a lack of inexpensive hotels or hostels would enable them to charge exorbitant prices for what was often poor-quality accommodation. ${ }^{38}$

Investments in tourist services like guest houses or canteens brought financial returns on a scale not to be found elsewhere; the construction would pay for itself after only two to four years. This led to the emergence of "developers"; organised and usually family groups of intermediaries who "often working in collaboration with officials and by putting pressure on land-owning highlanders, buy land from them and resell it a great profit. They also act as intermediaries in the organisation of construction works." ${ }^{39}$ Of particular interest to us are their links to town officials, without whom the whole venture would have been much more difficult or sometimes even impossible. Obviously, the most important roles were played by officials, who decided on the purpose of various plots and the town's possible pre-emptive rights to them, who also granted loans and construction materials, approved architectural designs and then supervised their implementation, many times failing to notice, for example, that the permissible floor area was considerably exceeded ${ }^{40}$ They failed to notice much more serious offences as well. As we read in a 1972 report, "there are cases when the supervising inspector, responsible for observance of the law, is also the designer of an illegally constructed building. The impudence of private capital can be illustrated [...]

38 IPN Kr, 030/1/7, Sprawozdanie z pracy operacyjnej Referatu ds. Bezpieczeństwa Publicznego KM MO w Zakopanem za IV kwartał 1958, 2 January 1959; SKULSKA, Wilhelmina. Dlaczego Zakopane? In Świat, 18 August 1958.

39 KOCHANOWSKI 2007, p. 82.

40 KĄKOL, Kazimierz. W obronie prawa. Co się dzieje w Zakopanem? In Prawo i Życie, 7 January 1973. 
by a house owned by A. Dziewicki, former manager of ZAiKS [Association of Stage Authors and Composers] houses. [...] The house was built across a road, in the line of a bridge, and as a result, the authorities were forced to build a new bridge and change the direction of the street. The owner of the house was not punished. Significantly, both the house, and the new bridge and road were designed by the same municipal architect of Z[akopane]."41

The involvement of municipal officials in the cutting of various construction-related Gordian knots was not necessarily merely associated with corruption and material gains, especially within the local networks. It may have been based on mutual "services" or caused by an understandable desire to rationalise one's work, or to resolve local conflicts. ${ }^{42} \mathrm{On}$ the other hand, various decision makers - top party and state leadership, heads of central institutions or directors of large enterprises-were similarly able to satisfy the aspirations of their subordinates' ambitions, from workers to senior officials, associated with "prestigious" holidays in Zakopane. This helped maintain peace in society, stabilising the system to a considerable degree for a reasonable price: the authorities gave up, usually consciously, only a small part of their prerogatives.

In the late 1960s and early 1970s, private individuals offered accommodation for around 16,000 tourists (including over 10,000 unregistered beds), twice as many as the entire state-controlled sector, both open (hotels and hostels) and closed (holiday houses belonging to enterprises) ${ }^{43}$ However, the biggest profits were guaranteed not so much through individual tourists, but by selling or leasing guest houses to enterprises. There is no doubt that they transferred-directly or via travel agencies-a vast majority of the funds to the pockets of private owners of guest houses or canteens. This is not surprising, as the ambition of many enterprises and institutions was - for the reasons outlined above-to have their own holiday house in some prestigious resort, ideally in Zakopane. New investment projects were banned in 1966, yet it was still possible to buy or lease a guest house. As some entities, especially large industrial conglomerates, had practically unlimited financial resources, attractive property was even auctioned and the owners received much more for it than they initially asked. Paying half the value of a guest house for an annual lease was not a rare occurrence either. ${ }^{44}$

No wonder that at the turn of the 1970s, the annual (legal and illegal) income of private entrepreneurs from Zakopane from room rentals, catering, transport, manufacturing, trade, illegal sale of alcohol etc. was estimated at over billion zlotys, more or less the same as the

41 KOCHANOWSKI 2007, p. 93.

42 IPN Kr, 030/32, Jan Roszkowicz, Notatka z rozmowy z adwokatem Władysławem Gajewskim, 26 January 1971 , p. 352; TENETA, Adam. Zakopane za łapówki. In Dziennik Polski (Kraków), 18-19 June 1972; Handlowali zakopiańskimi willami. In Dziennik Polski (Kraków), 18 December 1971. On the actions of officials, see LINDENBERGER, Thomas - LÜDTKE, Alf. Eigen-sinn: praktyki społeczne i sprawowane władzy. Wprowadzenie. In LINDENBERGER, Thomas - LÜDTKE, Alf (selection and introduction) - KONCZAL, Kornelia (ed.) Eigen-Sinn. Życie codzienne, podmiotowość i sprawowanie władzy w XX wieku. Poznań : Wydawnictwo Nauka i Innowacje, 2018, pp. 20-25.

43 Zakopiański tramwaj na niekontrolowanych torach. In Słowo Powszechne, 25 May 1967; AN Kr, KM PZPR Zakopane, 29/2272/101, Posiedzenie Egzekutywy KM PZPR w Zakopanem [Minutes of a meeting of the executive of the Municipal Committee],15 September 1972.

44 KOCHANOWSKI 2007, p. 86. We can only estimate that in the late 1960s and early 1970s, approximately 200 companies rented around 350 guest houses with 10,000 beds in Zakopane and its environs. AN Kr, KM PZPR Zakopane, 29/2272/101, Posiedzenie Egzekutywy KM PZPR w Zakopanem, 15 September 1972; KOCHANOWSKI 2007, pp. 80-81; KUŚMIEREK, Józef. Nie stać nas na takie Zakopane. In Życie Warszawy, 17 September 1972; Wille w Zakopanem. In Ekspress Wieczorny, 7 July 1971; MATZENAUER, Marian. Zakopiańska wiosna. In Trybuna Ludu, 1 June 1972. 
investment of the entire state-controlled sector in the town throughout the 1960s. ${ }^{45}$ This was a huge sum, prompting the private sector to control and corrupt officials, who did not put up much resistance. Predictably, both sides sought to maintain the status quo as long as possible.

Inevitably, every organisation is at risk of collapsing due to internal forces and external restrictions, and the "Zakopane consortium" was no exception as there were plenty of people willing to break or even blow up the petrified structures in Zakopane. Their reasons were similar to those which drove the anti-Semitic campaign of 1967-1968, largely generated by 30 and 40-year-olds who were pushing-effectively-the older generation out of their positions. These "youngsters", craving social, political and material advancement, were quite numerous in Zakopane, especially in sport or tourist circles. They had been waiting for the opportunity to take over posts held for ten years or longer by Zakopane apparatchiks entangled in the networks described above and strongly supported by the Gomułka elites. The fall of Władysław Gomułka in December 1970 caused a veritable earthquake in Zakopane. Security Services and prosecutors, unsure of what the new regime would bring and concerned about their own safety, ceased to protect existing set-ups, especially given that their Warsaw patrons had largely disappeared with Gomułka. The results of an investigation into the corruption of town officials revealing the scale of the "pathology" - which had been an open secret, in fact-contributed to a take-over by the youngsters of the highest party positions and municipal posts in the autumn of 1971 (Lech Bafia, b. 1932 and Stefan Gustek, b. 1934).

It did not take long for the effects to appear: half of the employees of municipal institutions were replaced; there was a purge in the Zakopane party structures and the police force; senior officials responsible for municipal services, construction and taxes were arrested and convicted, as were a dozen or so intermediaries and individuals for bribary. A campaign was launched to eradicate all local ills and transform Zakopane into a "socialist resort". ${ }^{46}$ An ostentatious demolition of several illegally constructed houses in November 1972 was intended to "demonstrate that no one can break the law with impunity, that it is impossible to intimidate and bribe the authorities." ${ }^{37}$ Houses constructed with official permission were checked with regard to the observance of the permissible floor area norms and an attempt was made to introduce rent control of private accommodations and to tax it.

However, this led not to a real seizure of control, but to the implementation of adaptation strategies by a majority of actors on the Zakopane scene, beginning with the highlanders and ending with the Central Committee of the Polish United Workers' Party. The reason was simple: in the mid-1970s, the number of visitors to Zakopane and the Tatra Mountains approached five million, almost twice as many as at the end of the Gomułka era. They would be accommodated not so much by the new hotels which were indeed being built, but private houses, where the number of beds increased by over 7,100 (including 6,000 unregistered ones $)^{48}$ over a period of a few years, and houses which continued to be built by various institutions (e.g. the Central Committee of the Polish United Workers' Party

45 KOCHANOWSKI 2007, pp. 84-85.

46 BRACKI, Maciej. Zbuduj dom w Zakopanem! In Fakty, 23 March 1975.

47 SMOCZYNSSKI, Juliusz. Zakopane w 5 lat później. In Kurier Polski, 7-9 May 1977.

48 AAN, IT, sign. 1069, A. Kołodziejczyk, Wplyw turystyki na ewolucję socjo-kulturowa ludności góralskiej regionu Zakopanego od 1900 r. do czasów najnowszych (1977), p. 73. 
and the Ministry of Internal Affairs) despite the ban. ${ }^{49}$ It was not possible to control all private houses, whose owners-including the risk in their pricing-rented rooms on their own and outside the tax system. ${ }^{50}$ No wonder that in 1978, the head of the local authority in Zakopane explained that "often administrative restrictions only give people more work, irritate interested parties and deepen corruption. They are ineffective and above all, they do not develop civic culture." 51

There is no doubt either that both town officials and party functionaries-representing Gierek's regime now-became as assimilated and entangled in the local networks as their predecessors. It is, therefore, not surprising that in the late 1970s, "illegal tourism" became as obvious as it had been a decade earlier. The rest was done by the economic crisis and the Solidarity revolution of 1980-1981. Consequently, as was noted in 1984, the gap between the "state" and the "private" sector became even more pronounced than had been suggested by a party analysis from twelve years earlier. ${ }^{52}$ In 1986, the head of the Polish United Workers" Party in Zakopane even admitted that "the expansion of private enterprise is in direct proportion to the demise of [...] state-owned companies. [...] It looks as if the state was consciously-I don't want to say deliberately-ceding the organisation of tourism and leisure to private entities. This concerns not only accommodation facilities, but also catering, trade, services etc." ${ }^{33}$

Still, the post-1989 political and economic transformation demonstrated that most phenomena described above occurred independent of time, system and party, a fact determined by a combination of various factors: geographical (the Tatra Mountains are still the only patch of Alpine landscape in Poland), historical and cultural (the myth of Zakopane is very much alive), social (society's increased wealth and radical expansion of the middle class) or economic (leisure time services are still the basic source of income for the local population and tax avoidance is still more profitable than the payment of taxes). The highlanders still relish their distinctiveness, or even uniqueness, while local officials, now part of true local self-government, are at even greater pains than before 1989 to avoid conflicts. As a result, the narratives around Zakopane in the first two decades of the $21^{\text {st }}$ century seem as if they have been taken straight from the 1960s or 1970s. An undiminished vogue for Zakopane drives-like it did half a century ago-investment, which, given strict regulations, generates construction without planning permission on a scale next to which the excesses from the Gomuła or Gierek eras look pitiful by comparison. ${ }^{54}$ Like in the Polish People's Republic, the number of non-registered and non-taxed beds is most likely higher than the number of legal ones, and their owners can feel as safe as they did in the 1960s.

49 MASZEK, Marek. Duże miasto pod małymi górami? Rozmowa z mgr. inż. Stanisławem Słodyczką. In Sztandar Młodych, 15-17 May 1981.

50 Raport z Zakopanego. In Gazeta Krakowska, 27 August 1975; PYKOSZ, Wojciech. Trudno rządzić pod Tatrami. In Życie Literackie, 21 March 1976; HIRNLE, Piotr. Tatry są jedne. In Polityka, 14 February 1976; MIGDAE, Konstanty. Baza dla milionów. In Dziennik Polski (Kraków), 12 August 1975; ADAMIECKI, Wojciech. Człowiek w tłoku. In Literatura, 7 April 1977.

51 Wiatr od gór. Rozmowa z mgr. Stanisławem Żygadło, naczelnikiem Zakopanego i Gminy Tatrzańskiej. In Kultura, 14 May 1978.

52 ORDYK, Tomasz. Kto rządzi w stolicy Tatr? In Przegląd Tygodniowy, 23 December 1984.

53 DĘBEF, Krzysztof. Zakopane nie jest dla mas. Rozmowa z I sekretarzem KM PZPR w Zakopanem, Andrzejem Wargowskim. In Sprawy i Ludzie, 22 May 1986.

54 KOPCIK, Ewa. Samowola po góralsku. Z widokiem na Giewont. In Dziennik Polski (Kraków), 13 October 2012, https://dziennikpolski24.pl/samowola-po-goralsku-z-widokiem-na-giewont/ar/3188018 [last viewed: 8 October 2021]; Cf. e.g. Tygodnik Podhalański, 9 June 2005, 3 February 2007, 2 April 2009, 1 December 2011, 28 February 2013; HAJOK, Dawid. Samowolka po góralsku, hej! In Gazeta Wyborcza, 3 November 2011, http://wyborcza. pl/1,76842,10579715,Samowolka_po_goralsku_hej_.html [last viewed: 8 October 2021]. 
"Zakopane is an informal economy Mecca," write Beata Sabała-Zielińska and Paulina Młynarska, experts on modern Zakopane. "Illegal accommodation is estimated at thousands of beds and is flourishing. [...] Mayors know about it, as do the district head and all kinds of officials. [...] We are talking about impressive guest houses and stylish villas, openly advertised in the press and on the internet! Is anybody prosecuting their owners? Is anybody checking them? Never! Unless an official receives a letter of denunciation citing justice and rule of law. [...] No harm will be done to the offender, however, if the regional authorities officially put the matter as follows: 'We will not saw off the branch on which the whole Zakopane is sitting, even if the branch should have never grown here.' The Inland Revenue is doing little as well, despite the fact that the 'offenders' are easy to find. Inspections of the several thousand illegal accommodation facilities apparently constitute such a big logistical and formal challenge that the Inland Revenue has basically given up on them." ${ }^{55}$

As one journalist from Zakopane summed it up, "it is a cross-party, timeless and absolutely demoralising problem. ${ }^{56}$ Like in the period before 1989, the government is not really concerned, appreciating as it does the legitimising significance of the Podhale region and Zakopane and exploiting it to build its image. While no VIP from Warsaw, no president, prime minister or even minister will ever be seen in a folk costume from Łowicz or Kraków, they are always happy to be photographed in a highlander's hat or sheepskin jacket with the mandatory shepherd's axe. "Are the hundreds of axes, hats or sheepskin vests given to Warsaw politicians for over the years part of a business deal or a mark of respect?" ${ }^{57}$ asked a Podhale weekly. Given that among those "quasi-highlanders" we have politicians from the left (Leszek Miller), centre (Lech Wałęsa, Donald Tusk, Bronisław Komorowski) and right (Lech and Jarosław Kaczyński, Andrzej Duda), I would choose the former.

55 SABAŁA-ZIELIŃSKA, Beata - MŁYNARSKA, Paulina. Zakopane. Nie ma przebacz. Bielsko-Biała : Wydawnictwo Pascal, 2014, pp. 72-73.

56 MRÓZ, Wojciech. Zakopane. Miasto cudów. Gdynia : Novae Res - Wydawnictwo Innowacyjne, 2015, p. 53.

57 Prawie górale. In Tygodnik Podhalański, 28 March 2019.

Cite:

KOCHANOWSKI, Jerzy. "Here a prosecutor fraternizes with a smuggler." Complicated Links Between the Mountains, Economics and Ideology. In Forum Historiae, 2021, Vol. 15, No. 2, pp. 38-50. ISSN 1337-6861. DOI: https://doi.org/10.31577/forhist.2021.15.2.4

Jerzy Kochanowski

Katedra Historii Kultury

Instytut Historii Sztuki Uniwersytetu Warszawskiego

Krakowskie Przedmiescie 26/28,

00-927 Warszawa

email: j.p.kochanowski@uw.edu.pl

https://orcid.org/0000-0002-6654-6204 